University of Montana

ScholarWorks at University of Montana

$1-2002$

\title{
Medieval Lyric: Genres in Historical Context by William D. Paden
}

Ashby Kinch

University of Montana - Missoula

Follow this and additional works at: https://scholarworks.umt.edu/eng_pubs

Part of the English Language and Literature Commons

Let us know how access to this document benefits you.

\section{Recommended Citation}

Kinch, Ashby, "Medieval Lyric: Genres in Historical Context by William D. Paden" (2002). English Faculty Publications. 3.

https://scholarworks.umt.edu/eng_pubs/3

This Book Review is brought to you for free and open access by the English at ScholarWorks at University of Montana. It has been accepted for inclusion in English Faculty Publications by an authorized administrator of ScholarWorks at University of Montana. For more information, please contact scholarworks@mso.umt.edu. 
William D. Paden, ed., Medieval Lyric: Genres in Historical Context. (Illinois Medieval Studies.) Urbana and Chicago: University of Illinois Press, 2000. Pp. viii, 371; blackand-white frontispiece, black-and-white figures, and tables. $\$ 39.95$.

Students and scholars of medieval poetry will want to spend some time with this intriguing volume, which gathers together a wide-ranging and thoughtful group of essays under the notoriously slippery generic category "medieval lyric." The fourteen essays, as Paden describes them, "range broadly over the lyric production of medieval Europe, centering on the Occitan troubadours but circling out toward French, Italian, German, Latin, Catalan, Spanish, Galician-Portuguese, Arabic, and Hebrew" (pp. 5-6). The common thread to the collection is a dynamic reevaluation of the concept of genre in understanding medieval lyric. Indeed, contributors throughout the volume find systems of generic classification most useful when they are in the course of expanding, revising, critiquing, or rejecting them. In the best tradition of scholarship on genre, the friction created by rubbing against the concept of genre sparks the most provocative insights in these essays. 
In an eloquent and succinct introduction Paden outlines his approach to genre, which refreshingly restores the artistic energy to the study of medieval poetic creation by valuing the imaginatively productive quality of genre over the taxonomic accuracy of generic classification. The goal of the volume is not to produce a critically comprehensive system of medieval genre but rather, as Paden puts it, to "enable us to appreciate its dynamism, its pulls and tugs, rather than, simply and thoughtlessly, to accept its static results" (p. 5). As a signal of his affiliation with the poet-as-artist, Paden's introduction contains several interartistic analogies (to manuscript illumination, art theory, and architecture criticism), which usefully prompt the reader to think of lyric in broader aesthetic terms than is customarily practiced in medieval lyric scholarship.

The essays, which substantially vary in length (from twelve to forty-six pages), also substantially differ in both the quality of the prose and the polish of the argument, a problem inherent in all essay collections, though perhaps more starkly observed here. Readers less familiar with the material will appreciate that several of the contributors include full texts of the poems they discuss at length. The book is divided into four sections, though Paden notes that "it is a mark of the coherence of the collection that many of the essays participate in more than one of these foci" (p. 5). The essays certainly do engage one another across the editorial divisions, giving the collection the feel of an extended, open conversation conducted over time by scholars with considerable common purpose.

The six essays in the first section, "Genres in History," are perhaps the most heterogeneous in approach, no doubt because of the divergence in interpreting "history." Three of the essays provide macrocosmic readings of the lyric tradition they analyze by offering philological and statistical evidence for major shifts within a given genre system: William Paden's "The System of Genres in Troubadour Lyric," Ana María Gómez-Bravo's "Decir canciones: The Question of Genre in Fifteenth-Century Castilian Cancionero Poetry," and Michelangelo Picone's "Traditional Genres and Poetic Innovation in Thirteenth-Century Italian Lyric Poetry." Readers whose appetites are whetted by Picone's breathless, sevenpage sprint will want to consult Olivia Holmes's new book, Assembling the Lyric Self: Authorship from Troubadour Song to Italian Poetry Book, which thoroughly examines the same question. In " 'Cobleiarai, car mi platz': The Role of the Cobla in the Occitan Lyric Tradition," Elizabeth Poe rehabilitates a neglected troubadour genre by showing the cultural variety and ingenuity of poets who wrote in it.

Two essays in this section really stand out for the way they innovate by asking new questions. Winthrop Wetherbee's "The Place of Secular Latin Lyric" argues for renewed attention to the subtlety of language and concept in secular Latin lyric poetry by focusing on the way the learned Latin tradition transmits a distinctive ironic perspective on the better-known vernacular love lyric tradition. His essay makes an excellent case for reuniting study of the vernacular and Latin lyric traditions, if only to show their dynamic conceptual tension. Meanwhile, Julian Weiss, in "On the Conventionality of the Cantigas d'amor," creatively argues that Galician-Portuguese poets signal their participation in a prestigious social group by conforming themselves to the conventional expectations of an accepted poetic idiom, which offers stylistic means for individual distinction within established poetic boundaries. Weiss's argument, which will be well received by scholars dissatisfied with the limited critical dyad "sincerity-originality," exemplifies the best of contemporary scholarship that gives new value to medieval lyric by providing an explanatory, social frame.

The first three of the four essays in the second section, "Genre and Rhetoric," hang together by offering new accounts of the fluid, creative interaction between vernacular poetry and the new poetic theory reflected in Occitan and Old French "arts of poetry." Douglas Kelly, "The Poem as Art of Poetry: The Rhetoric of Imitation in the Grand chant courtois"; Rupert T. Pickens, "The Old Occitan Arts of Poetry and the Early Troubadour Lyric"; and John Dagenais, "Genre and Demonstrative Rhetoric: Praise and Blame in the 
Razos de trobar and the Doctrina de compondre dictats," all creatively reinterpret the specific ways later poetic theorists in the emerging vernacular tradition respond to prior poetry through the lens of contemporary generic expectations and poetic interests. Taken together, these three essays present a compelling case for Paden's editorial interest in examining the "historicity of genres themselves as terms and concepts" (p. 5). These essays also join a growing body of scholarly work on self-reflection in medieval vernacular poetry. By evaluating the complexity and depth of medieval aesthetic systems without the encumbrance of a "Renaissance" narrative of cultural development, scholars are finding interesting new arguments for the aesthetic integrity of medieval lyric. I could find no rationale for including in this section Vicente Cantarino's "Wa-hiya taklifu ghannat': Genre and Gender in Hispano-Arabic Poetry," which addresses "rhetoric" in only the most tangential of ways. Hesitant and speculative, Cantarino muses without concluding, gathering his ideas on the link between genre and gender without a clear guiding thesis.

The two essays in the third section, "Genre and Music," make the most distinctive contribution to the volume by using musical theory to revitalize our understanding of specific lyric genres, thus forming a bridge between disciplines too often studied separately. In "Genre as a Determinant of Melody in the Songs of the Troubadours and the Trouvères," Elizabeth Aubrey demonstrates that the Aristotelian concept of rhetorical propriety may have influenced the way Occitan poets linked specific poetic genres with musical forms believed to produce psychological effects consonant with the principal theme of the genre. In "Intergeneric Play: The Pastourelle in Thirteenth-Century French Motets," Sylvia Huot exercises her prodigious reading skills to elucidate the striking artistic effects created when the pastourelle is appropriated by a new musical form, the motet, whose "polyphonic format allowed for new ways of exploiting [the pastourelle's] stock characters and situations" (p. 297). Both arguments imply that medieval poets and musicians used musical form to create a nexus of complex intergeneric references, adding layers of meaning through musical allusion, much as today's hip-hop and electronic forms use sampling to indicate affinities of idea and style.

In the fourth section, "Questioning Genre," both Ross Brann, “"The Fire of Love Poetry Has Kissed Me, How Can I Resist?" The Hebrew Lyric in Perspective," and Hubert Heinen, "Thwarted Expectations: Medieval and Modern Views of Genre in Germany," question the use value of taxonomic systems of genre in understanding their respective topics, though, indeed, both scholars rely on the recognizable distinctions of specific genres to make their argument. Brann claims that "Hebrew lyric resists efficient generic mapping," arguing against "formalist readers [who] have endeavored to reconstruct the generic codes according to which the poems were understood" (p. 329). The essay reads like a preface to a more provocative argument that Brann may be pursuing. "The sheer messiness of composite poems" (p. 329) in Hebrew lyric would make a fascinating study focused on the aesthetics of genre blending. Heinen uses examples of Tagelieder, or "dawn songs," to show that the best German lyric practitioners eschewed genre conventions in favor of a "delightfully playful manner" in which they "used sprinklings of generic allusions to arouse and thwart their audiences' expectations" (p. 343). Although he claims that "in the Middle Ages Germany never developed a system of genres," the concept of "audience expectation" requires him nonetheless to invoke a "deep awareness of genre" (p. 342) in even the most radical deviation from the perceived standard form. The Tagelied may not have been systematized, but Heinen is not arguing that it does not exist, merely that modern scholarly descriptions have not accounted for the idiosyncratic features of its most interesting examples. After Jauss, no scholar should feel compelled to argue against a "system of genre," which has, after all, a primarily heuristic value, when what they want to do is argue for a deeper, conceptual approach to genre.

Curiously, this collection of essays purporting to "range broadly over the lyric produc- 
tion of medieval Europe" does not discuss a single poem in Middle English. In his defense, Paden has not disguised his parochialism (Occitan at the "center"; see the quotation above) nor claimed to provide a comprehensive collection; and certainly troubadour poetry has earned a place of prestige in discussions of medieval lyric. But given the inclusion of German, Hebrew, and Arabic poetry, the omission cannot be defended on linguistic grounds. More importantly, the omission represents a significant missed opportunity, especially given the demonstrable influence of troubadour and trouvère writing on Middle English poetry. As an example, an essay on the Harley lyrics, which playfully tweak Continental lyric forms in a distinctively Middle English idiom, would have provocatively contributed to the discussion of historically and culturally specific adaptations of genre, Paden's avowed-and important-goal for the volume.

Quibbles aside, the collection vividly demonstrates that a subtler appreciation of medieval lyric on its own generic terms yields rich and unexpected rewards. The diversity of methodology and topic in these essays illuminates the sophistication of the present state of medieval lyric scholarship and ought rightly to spur another generation of scholars to pursue the elusive art of reading medieval lyric.

Ashby KInCH, Christopher Newport University 